notes on terms of engagement suitable for physicists is being prepared. The appointments register has been discontinued, but notices of vacancies for physicists have been included in the monthly Bulletin, and from the steadily increasing demand from employers for such space it would appear that this new procedure is satisfactory.

\section{FIRST NATIONAL POLISH SCIENCE CONGRESS}

$\mathrm{T}$

HE First National Polish Science Congress was held at Warsaw during June 29--July 2, in the magnificent hall of the reconstructed Polytechnic Institute. The Congress was called together to deal chiefly with the reorganization of science in Poland, and the discussions, therefore, concerned administrative problems rather than the details of scientific researches as such. Nevertheless, it was of great importance for Polish science, which lost some 40 per cent of its personnel, and suffered widespread destruction of buildings and equipment in the Second World War. Re-organization was required by the great expansion of facilities and numbers of newly trained scientific workers. It had come to be felt on all hands that a unified National Academy of Sciences was a necessity.

The principal formal business of the Congress consisted, therefore, in the incorporation of the former leading scientific organizations, such as the Cracow Academy of Sciences (Polskie Akademie Umietnosci) and the Scientific Society of Warsaw (Warszawska Towarzystwo Naukowe), both dating from the early years of the nineteenth century, into the new National Academy. The Cracow Academy had always been an honorific and essentially publishing body, while the Warsaw Society, though partly concerned with popularization of science (like the British Association), had come to possess a number of research institutes of its own. The new National Academy, modelled on those of the U.S.S.R., China and other countries, will now possess a network of research institutes, and the academicians will be mainly directors of institutes or departments of institutes.

Preparations for the Congress had involved more than a hundred conferences and meetings covering all branches of science and technology. At these meetings there had been discussion of the best arrangements for the organization of the new institutes. At the Congress itself it was emphasized, in the speech of the president (Dr. Jan Dembowski, zoologist), that during the period of re-organization there would be the minimum interruption of research projects currently under way. But besides these problems, the preliminary meetings had evidently also devoted much time to discussion of theoretical problems in the various sciences-a process no doubt stimulated by the desire of the younger generation of Polish men of science to incorporate the philosophy of dialectical materialism into the background of their thought. The interesting speeches of Dr. Dembowski and of Dr. K. Petruszewicz at the opening plenary sessions were made available to foreign representatives in languages of Western Europe, and it would seem very desirable that they should be published in some way in Great Britain.

Foreign countries were represented by small groups of up to about half a dozen members. The Soviet delegation, headed by Prof. Oparin, the biochemist, was naturally the largest; but there were also delegations from France, Germany, China, Hungary, Sweden, Rumania, etc. From the United Kingdom, Dr. J. Needham brought a message of greetings to the new National Academy from Prof. E. D. Adrian, president of the Royal Society. The foreign representatives were able to listen to the speeches in simultaneous translation, and had the opportunity of meeting a very large number of Polish scientific workers of all generations and all specialities. There can be no doubt that the Congress, and the Academy which it was called upon to found, represent an important step forward in the organization of science in Poland.

J. NeEdHaM

\section{CRYSTAL STRUCTURE OF A LOW MOLECULAR WEIGHT PROTEIN \\ Electron Microscopy of $\beta$-Lactoglobulin Crystals}

GLECTRON microscopy of protein erystals has in the past been concerned solely with proteins or nucleoproteins of high molecular weight $t^{1-3}$. In this investigation the electron microscope reveals structure in crystals of a protein of a much lower molecular weight, namely, $\beta$-lactoglobulin, molecular weight 36,000 , which has already been examined by $\mathrm{X}$-ray diffraction methods ${ }^{4}$.

Preparations for the electron microscope were made according to the pseudo-replica technique of Wyckoff ${ }^{3}$, the specimens being shadow-cast with palladium before stripping from the glass surface. The bulk of lactoglobulin was dissolved out in water before examination of the replica.

The accompanying micrograph is typical of the results. It shows the (100) face. The striations on the crystal face are parallel to the $b$-axis of the erystal. The periodicity is $105 \pm 5 \mathrm{~A}$. Molecular steps similar to those shown in earlier published pictures of $n$-hexatriacontane $e^{5,6}$ occur on the crystal

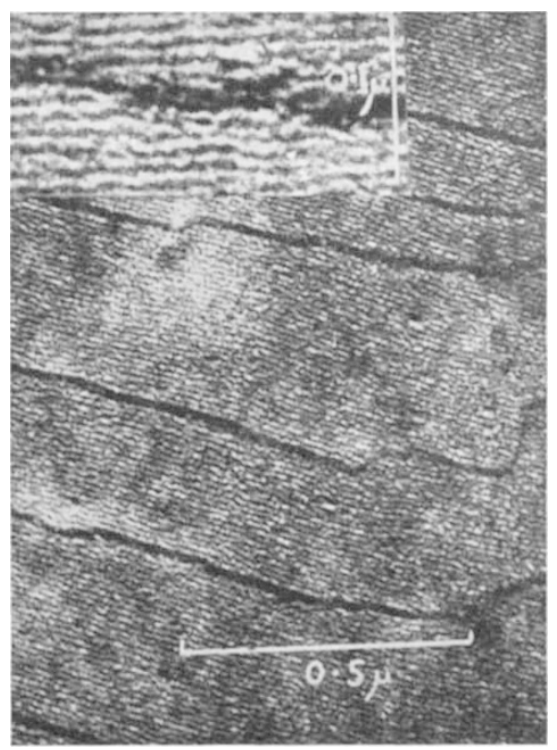

